\title{
Influence of Tool Geometry of Reversible Shovel on Soil Disruption
}

\author{
Abhinav Yadav ${ }^{*}$, Ajay Kumar Sharma ${ }^{2}$, Vipin Laddha ${ }^{1}$, \\ Manpreet Singh ${ }^{1}$, Brajesh Kumar ${ }^{3}$ and Anurag Yadav ${ }^{4}$ \\ ${ }^{1}$ FIMTTC, S. K. Rajasthan Agriculture University, Bikaner-334006, India \\ ${ }^{2}$ CTAE, M. P. University of Agriculture \& Technology, Udaipur-313001, India \\ ${ }^{3}$ College of Agriculture Engineering \& Technology, Etawah-206001, India \\ ${ }^{4}$ Sardar Vallabhbhai Patel University of Agriculture and Technology, Meerut - 250110, India \\ *Corresponding author
}

\section{A B S T R A C T}

\section{Keywords}

Reversible shovel, Soil profiles,

Crescent height,

Spoil area, Trench area

Article Info

Accepted:

14 November 2020

Available Online:

10 December 2020
Reversible Shovels type furrow openers are simple in design and because of their simple low-cost construction; they are widely used in cultivator for opening the soil. The study was conducted on the soil disruption by tractor operated cultivator type reversible type furrow openers to improve soil conditions in sandy loam soil using four types of furrow openers at operational speed and depth of operation of $(1.53,1.81) \mathrm{m} / \mathrm{sec}$ and $(14,16) \mathrm{cm}$ respectively. Tool T-4 gave more spoil furrow width, spoil furrow depth, crescent height, spoil area and trench area.

\section{Introduction}

Agriculture is the most important sector of Indian Economy. Agriculture in India is unique in its characteristics having about 250 different crops cultivated in different agro climatic zones. Indian agriculture sector accounts for 18 per cent of India's gross domestic product (GDP) and provides employment to $50 \%$ of the countries workforce. Indian is an agriculture-based country, where more than $50 \%$ of population is depend on agriculture (Madhusudhan,
2015). Agriculture in India is currently growing at an average compound annual growth rate (CAGR) of 2.8 per cent (Mehta $e t$ al., 2014). India's arable land area of 159.7 million hectares (394.6 million acres) is the second largest in the world, after the United States (Himani 2014). Agricultural engineering inputs have played an important role in increasing production through appropriate mechanization (Manchikanti and Sengupta, 2012). The total farm power availability in Indian agriculture was 2.24 $\mathrm{kW} /$ hain 2016-17. It had a share of 1.324, 
$0.018,0.021,0.460,0.193,0.091$ and 0.130 $\mathrm{kW} / \mathrm{ha}$ from tractors, powertillers, combine harvesters, diesel engines, electric motors, humans and draught animals, respectively (Mehta et al., 2019). The growth in largescale adoption of agricultural tools and machinery in the country has been possible due to efforts not only by organized sectors but also by village craftsmen and small-scale industries. Cultivator is one of the most important tillage tools used by Indian farmer (Yadav et al., 2006). Even many organic farmers say that a pass with the cultivator has the same effect on the crop in dry weather as a half inch of rain (Klaas and Mary-Howell Martens, 2005). It is primarily the type of tillage implement which is used for opening the land, preparing the seedbed for sowing of the seeds as well as after the crop has come up a few cms above the ground (Jain and Grace Philip, 2003). The field cultivators are often used as secondary tillage tools for seedbed preparation. Reversible shovel, sweep, half sweeps, furrower etc. are the different types of tools that can be attached to a cultivator shank for different applications. Reversible shovel and sweep are primarily used for loosening and steering the soil. They are used on cultivators and are recommended for secondary tillage operation but most of the farmers also use this shovel for primary cultivation. They are used in seed drills for opening the furrow for placement of seeds. They do not usually have an inverting effect and penetrate more easily in hard grounds because of less upward soil reaction (Chen et al., 2004).Both soil condition and soil physical characteristics like structure and texture demand different shapes of soil working tools as well as operating conditions. Hence, soil-tool-tillage complex need to be studied for a given location and tool geometry and is to be optimized for better tool performance and energy (Yadav et al., 2006). Keeping these in view, a study was conducted to provide information on soil disruption for selected shovels for tractor drawn cultivator to improve soil conditions.

\section{Materials and Methods}

The experiment using factorial RBD design were conducted in indoor soil bin filled with locally available sandy loam soil at the Department of Farm Machinery and Power Engineering, College of Technology and Engineering, Udaipur, Rajasthan, India. The shovels were purchased from locally available in the Udaipur region as shown in fig. 1. The experiment set-up comprised of an indoor soil bin, a power transmission unit, control panel, tool frame and a soil compaction unit. The size of the indoor soil bin used was $20400 \mathrm{~mm} \times 2300 \mathrm{~mm} \times 600 \mathrm{~mm}$. The power from a $2.24 \mathrm{~kW}$ DC variable shunt wound motor was transmitted to the wheels of a trolley through belt and pulley arrangement (Fig. 2). A regulator was used to increase or decrease the speed of the motor for obtaining the desired operating speed of the tools. During the test, the average cone index, measured by a field scout digital cone penetrometer, was $1154 \mathrm{kPa}$ up to a depth of $100 \mathrm{~mm}$ as a measure of soil strength. The soil moisture of $9-12 \%$ (db.) was maintained during the experiments. These values are normally observed in field during tillage operations in the region. Table 1 gives the details of various parameters considered in the study.

\section{Tool trolley unit}

Tool trolley frame of size 2470 x $1510 \mathrm{~mm}$ was fabricated to provide platform for installation of power transmission unit and tool frame assembly. The frame of the tool trolley was rectangular in shape. This was mounted on forecast iron wheels of diameter $220 \mathrm{~mm}$ resting on test track. Pedestal bearings were used to mount the tool trolley frame on $50 \mathrm{~mm}$ diameter axle. The tool 
trolley frame was fabricated by ISMC $100 \times 50$ mm (Fig. 3A).

\section{Soil processing trolley unit}

Soil processing unit consists of a rotavator, roller and leveler assembly. Overall length and width of the soil preparation assembly was $2470 \mathrm{~mm}$ and $1510 \mathrm{~mm}$ respectively. Also, the lengths of the rotavator and leveler assembly were $1460 \mathrm{~mm}$ and $1530 \mathrm{~mm}$ respectively. It consisted of 12 ' $\mathrm{L}$ ' type blades rotating at a speed of $270 \mathrm{rpm}$. Drive was given to the rotavator blades through a motor. Initially, rotavator was operated to pulverize the soil followed by leveling of the soil by the leveler. The roller assembly made the soil compact after the rotavator and leveler operation (Fig. 3B).

\section{Tool frame and tyne}

A tool frame $(1000 \mathrm{~L}$ x $306 \mathrm{~W}, \mathrm{~mm})$ was fabricated by $30 \mathrm{~mm}$ MS square section to test cultivator shovels in the soil bin (Fig. 4A). It was clamped on the horizontal beam of tool trolley unit. The tool was clamped on a sliding frame on the main frame. The sliding frame arrangement took care of up and side thrust forces developed during the operation. Depth of operation was adjusted by adjusting the height of clamped tyne. An arrangement was provided to fixed load cell between the main frame and the clamp to which tyne was clamped. The tyne $(47.72 \mathrm{~W} \times 18 \mathrm{~T}, \mathrm{~mm})$ used for mounting reversible shovels has made from MS flat (Fig. 4B).

\section{Soil disruption}

Soil disruption can be classified as surface and subsurface soil disturbance. The surface soil disturbance or spoil is a measurement of the amount of soil displaced above the original soil surface by the tillage process and subsurface soil disruption is the area that is disrupted below the soil surface and trenched area (Raper and Sharma, 2004).

Soil disruption was measured with the help of soil profilometer (Fig. 5). The profilometer was fixed across the trench and the main scale was adjusted with knobs and spirit level to keep it horizontally leveled. With the help of plum bob, the vertical depth or height of the soil surface was determined at every $2 \mathrm{~cm}$ horizontal distance on the main scale. Replicated observations of soil disruption were recorded for each tillage tool. After completion of surface disruption measurement, the profilometer was kept installed and the manipulated soil mass was removed from the trench below the profilometer with hand without disturbing the instrument. Care was taken to ensure that only soil loosened by tillage was removed. The area of soil profile was calculated. The penetrometer was inserted in the soil at the rate of $25-30 \mathrm{~mm} / \mathrm{s}$ and replication observations were recorded.

\section{Results and Discussion}

The analysis of variance (ANOVA) showed that the shovel, speed, depth of operations and their interactions affected the spoil and trench area significantly.

\section{Effect of shovel, speed and depth of operation on soil profile of shovels}

Figures 6 to 9 show the spoil and trench profiles created by fours shovels at different speeds and depths. It is clear from the figure that the spoil furrow width and spoil furrow depth increased with increase in either speed or depth for all the shovels. This may be attributed to increase in tillage speed and depth which resulted in tossing of more soil and redistributing it in a wider length outside the trench. Similar findings are also reported by Liu and Kushwaha (2006). Maximum spoil 
furrow width was observed for T-4 at $16 \mathrm{~cm}$ depth of operation at $1.81 \mathrm{~m} / \mathrm{s}$ forward speed whereas minimum spoil furrow width of was observed for T-1 at $14 \mathrm{~cm}$ depth of operation at forward speed of $1.53 \mathrm{~m} / \mathrm{s}$. Also shovel T-4 gave highest values of crescent height and forward and furrow depth than all other shovels within the test range of depth of operation and forward speed. This may be attributed to spear shape of T-4 which resulted in higher values as compared to other shovels. Hanna et al., (1993) had also reported that wider shovels behave in a similar manner.
Effect of shovel, speed and depth of operation on spoil area

Figure 10 shows that spoil area increased with increase in depth and speed of operation for all shovels. However, T-4 resulted in more spoil area than all other shovels at all depths and speed of operation. It is also observed that for shovel $\mathrm{T}-1, \mathrm{~T}-2$ and $\mathrm{T}-3$, the effect of depth of operation was more dominant at 16 $\mathrm{cm}$ depth of operation. This may be attributed to shape of T-4 which might have resulted in this way.

Table.1 Parameters considered in the study

\begin{tabular}{|c|c|c|c|}
\hline S. No. & Parameters & Levels & Particulars \\
\hline \multicolumn{4}{|c|}{ A. Tool Parameter } \\
\hline $\mathbf{a}$ & Reversible shovel & 4 & $\begin{array}{l}\begin{array}{l}\text { T1,T2,T3 and } \\
\text { available }\end{array} \\
\text { T4 commercially }\end{array}$ \\
\hline \multicolumn{4}{|c|}{ B. System Parameters } \\
\hline $\mathbf{a}$ & Speed, $\mathrm{m} / \mathrm{s}$ & 2 & $1.53,1.81$ \\
\hline b & Depth, cm & 2 & 14,16 \\
\hline \multicolumn{4}{|c|}{ C. Soil Parameters } \\
\hline $\mathbf{a}$ & Soil Type & 1 & Sandy loam soil \\
\hline b & Moisture Content, db & 1 & $9-12 \%$ \\
\hline \multicolumn{4}{|c|}{ D. Parameters to be observed } \\
\hline $\mathbf{a}$ & Soil disruption, $\mathrm{m}^{2}$ & & \\
\hline \multicolumn{4}{|c|}{ E. Soil profile } \\
\hline $\mathbf{a}$ & $\begin{array}{l}\text { Spoil furrow width, } \\
\mathrm{m}\end{array}$ & & \\
\hline b & Spoil furrow depth, m & & \\
\hline c & Crescent height, $\mathrm{m}$ & & \\
\hline d & Spoil area, $\mathrm{m}^{2}$ & & \\
\hline $\mathbf{e}$ & Trench area, $\mathbf{m}^{2}$ & & \\
\hline
\end{tabular}


Fig.1 Commercially available shovel (all dimensions are in $\mathrm{mm}$ )

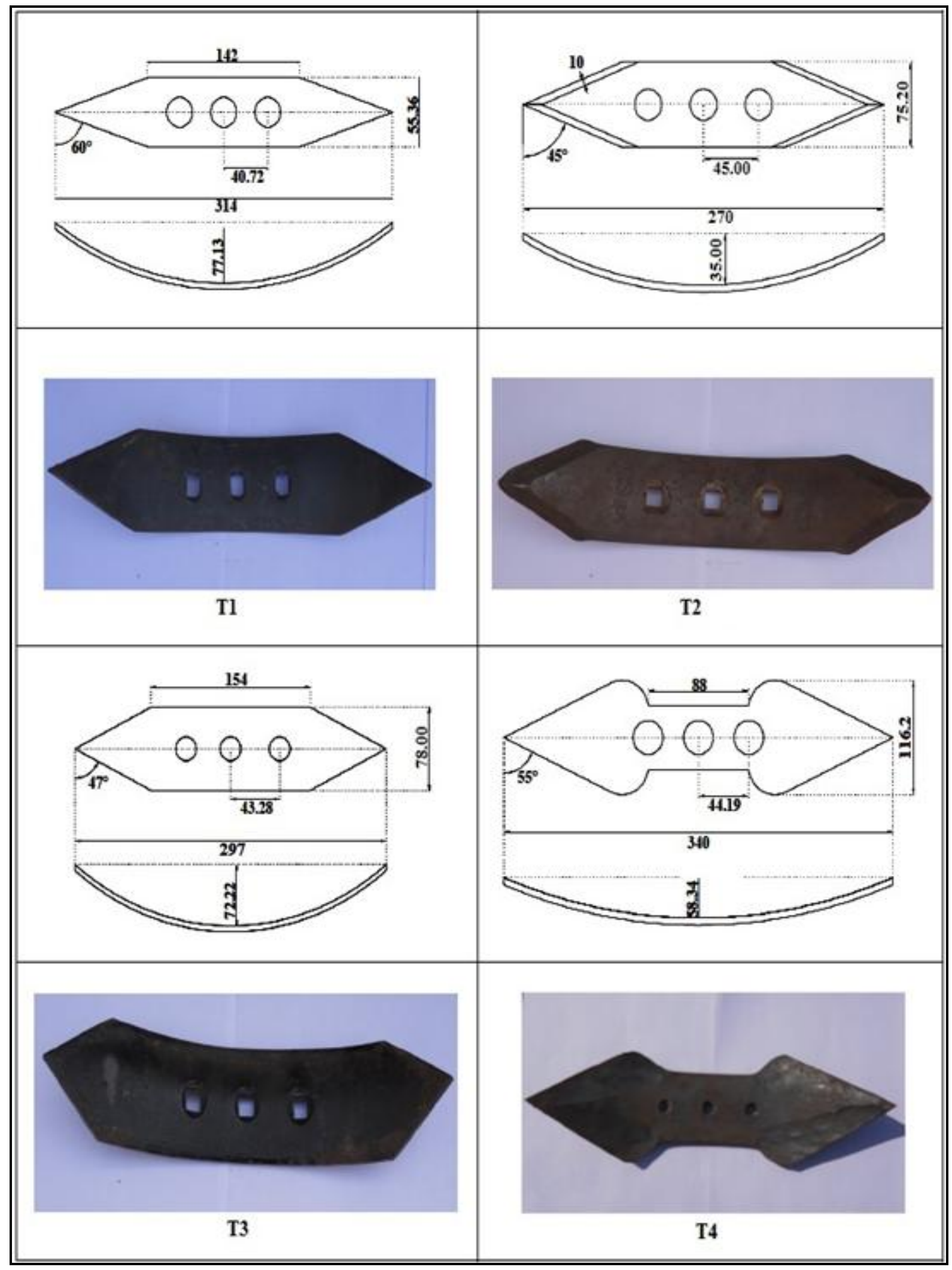


Fig.2 Schematic diagram of experimental setup

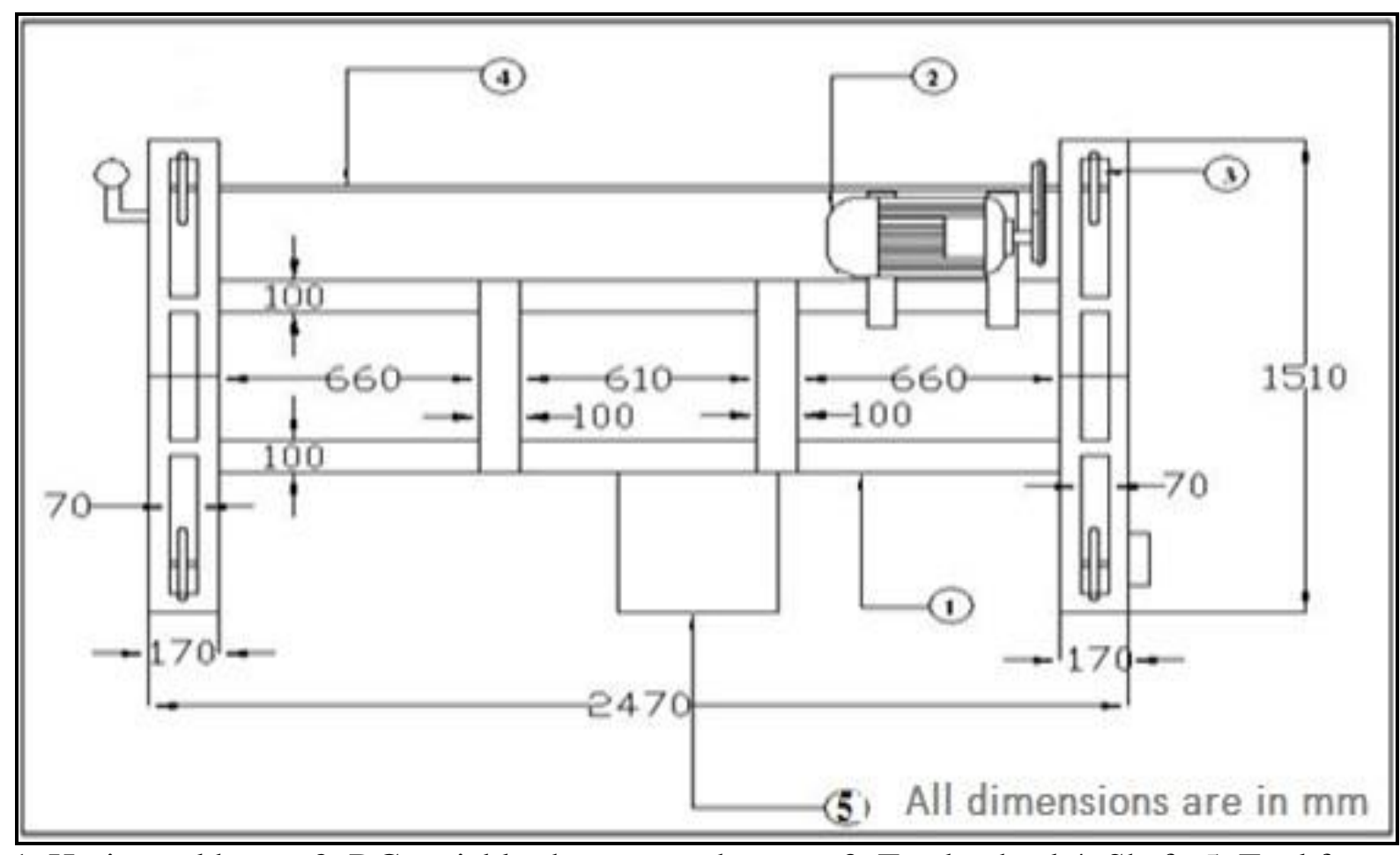

1. Horizontal beam, 2. DC variable shunt wound motor, 3. Track wheel,4. Shaft, 5. Tool frame

Fig.3 Actual view of experimental system

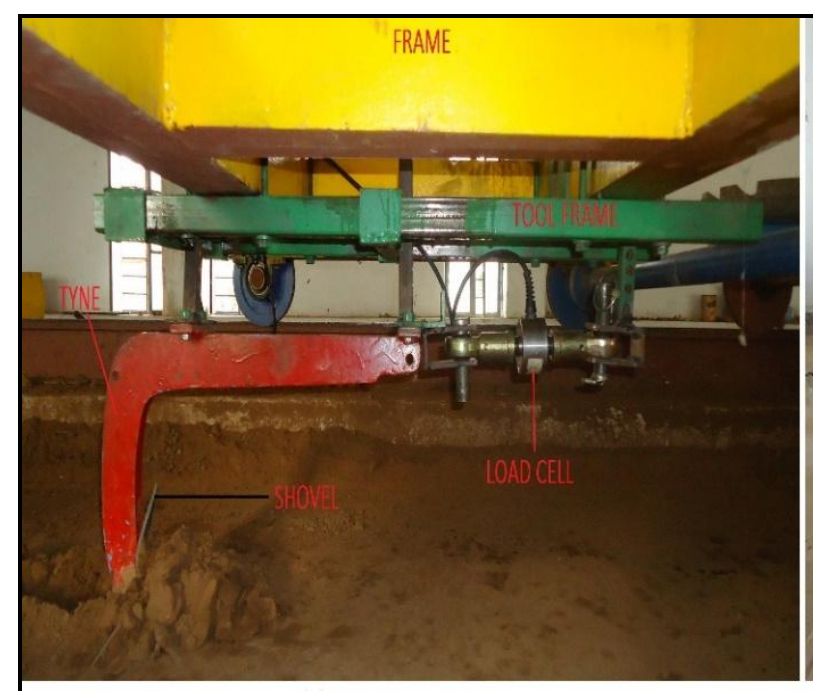

(A) TOOL TROLLYUNIT

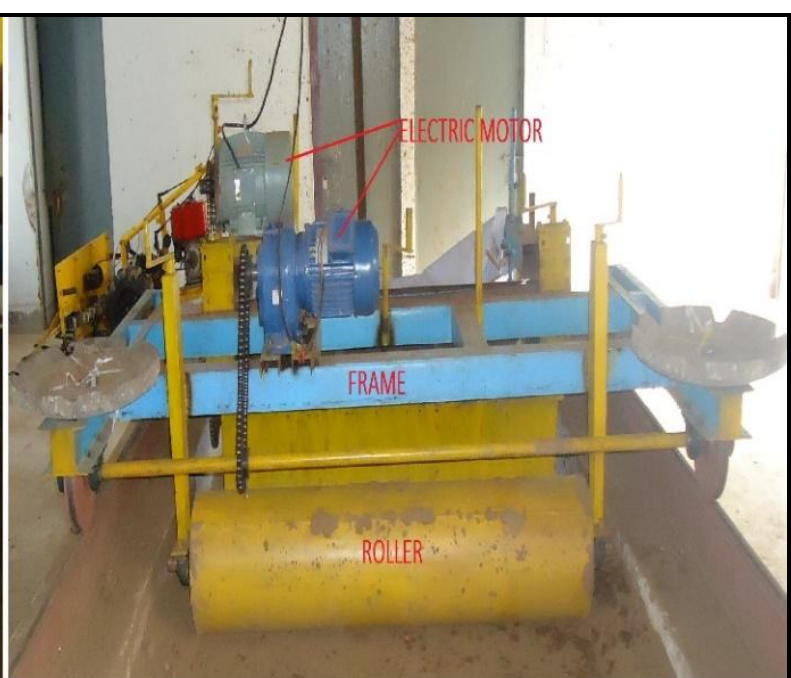

(B) SOLL PROCESSING TROLLEYNIT 
Fig.4 Schematic view of tool frame and tyne (all dimensions are in $\mathrm{mm}$ )

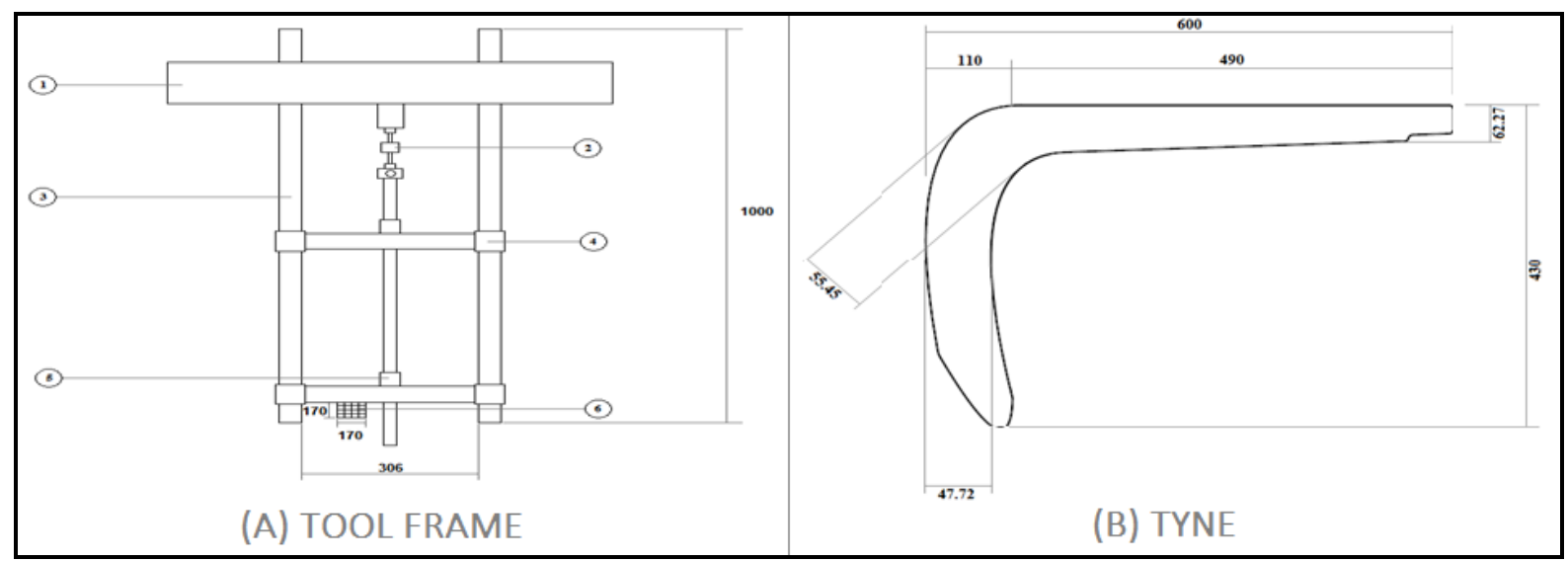

1. Horizontal beam, 2. Load cell, 3. Tool frame, 4. Sliding bar, 5. Tool clamp, 6. Load cell indicator

Fig.5 Schematic view of profilometer for measurement of soil disruption

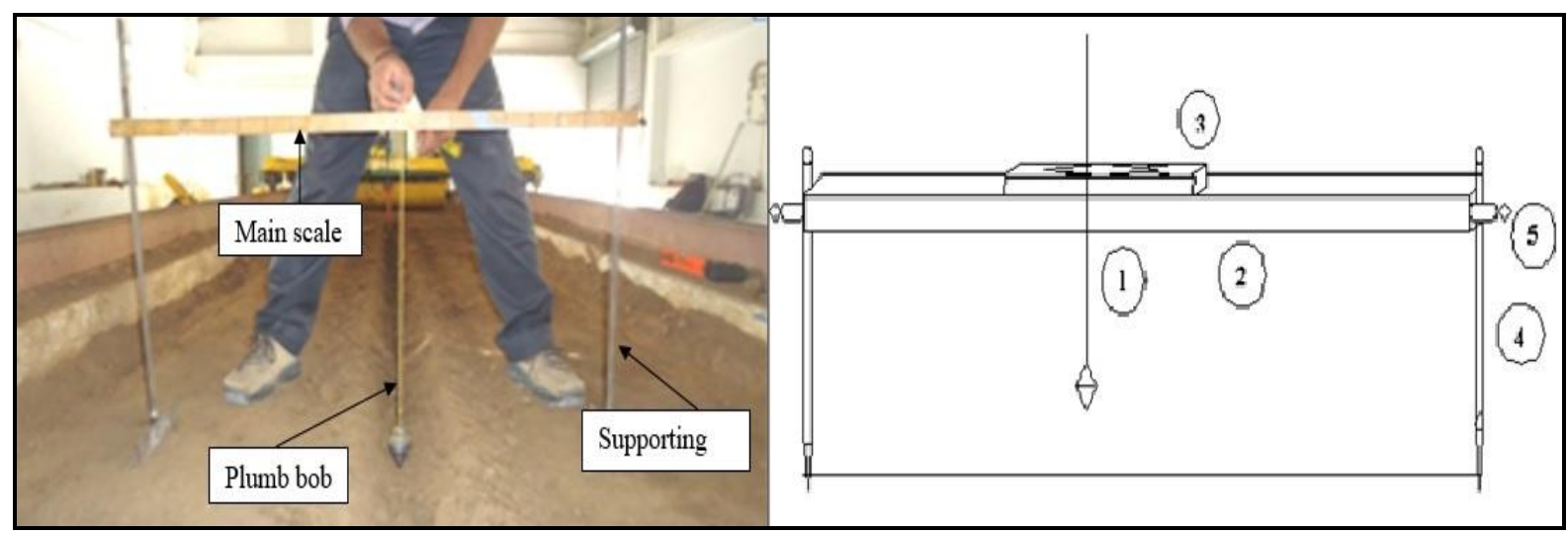

1. Plumb bob, 2. Horizontal scale, 3.Sprit level, 4.Supporting rod, 5.Knob

Fig.6 Spoil and trench profile at different speeds and depths of operation for T-1
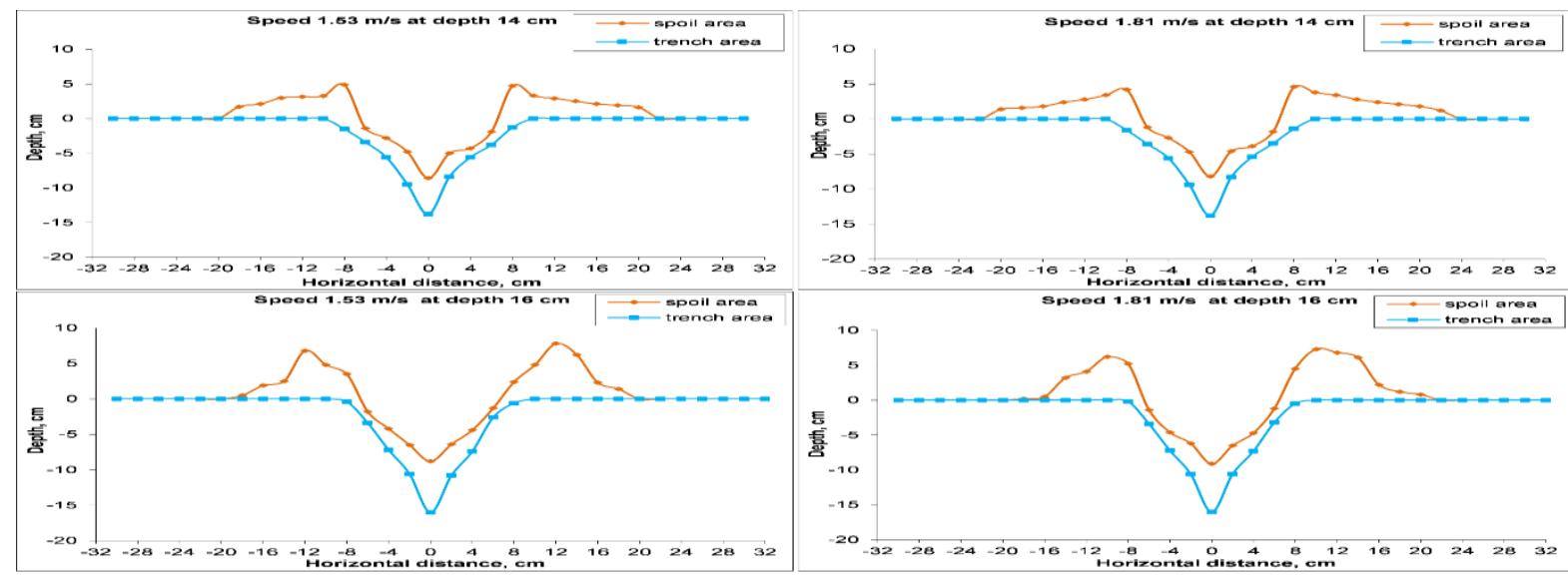
Fig.7 Spoil and trench profile at different speeds and depths of operation for T-2
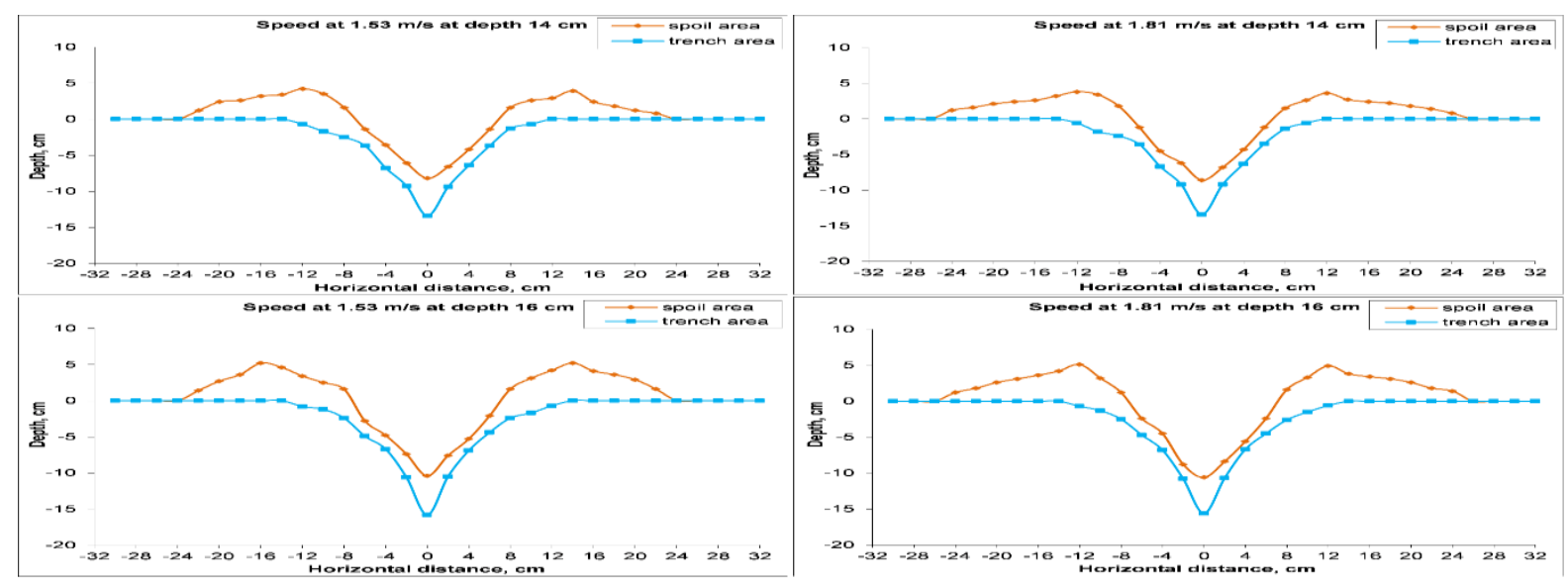

Fig.8 Spoil and trench profile at different speeds and depths of operation for T-3
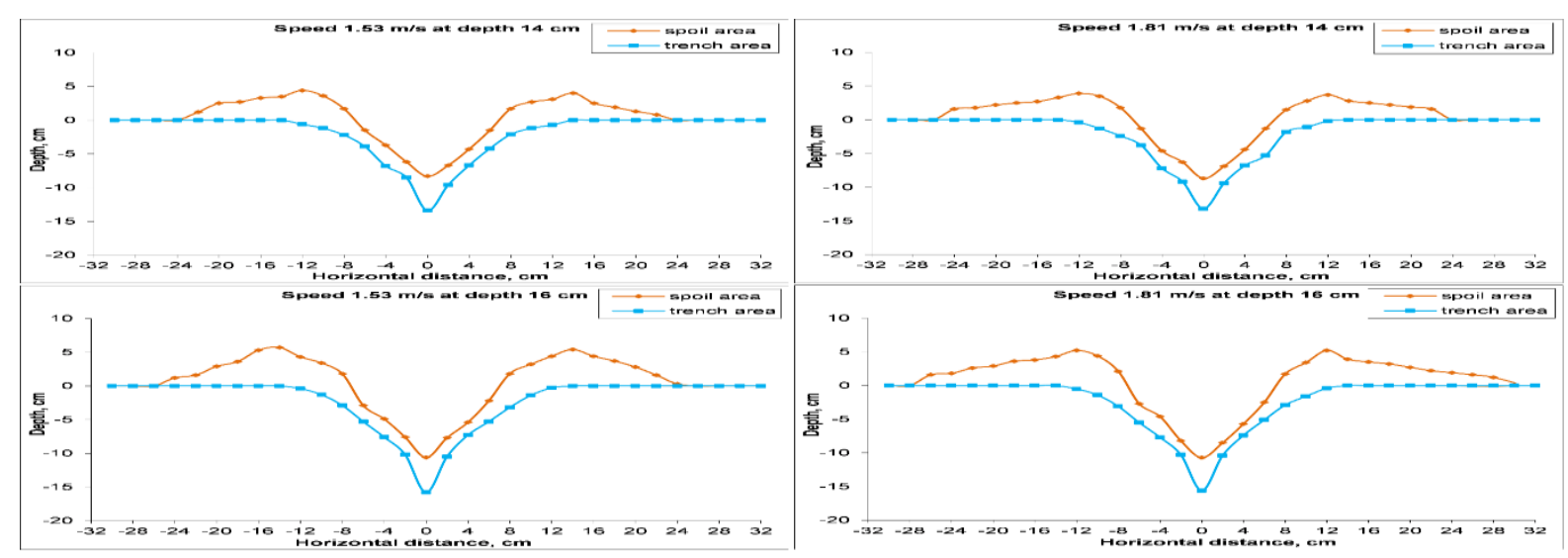

Fig.9: Spoil and trench profile at different speeds and depths of operation for T-4
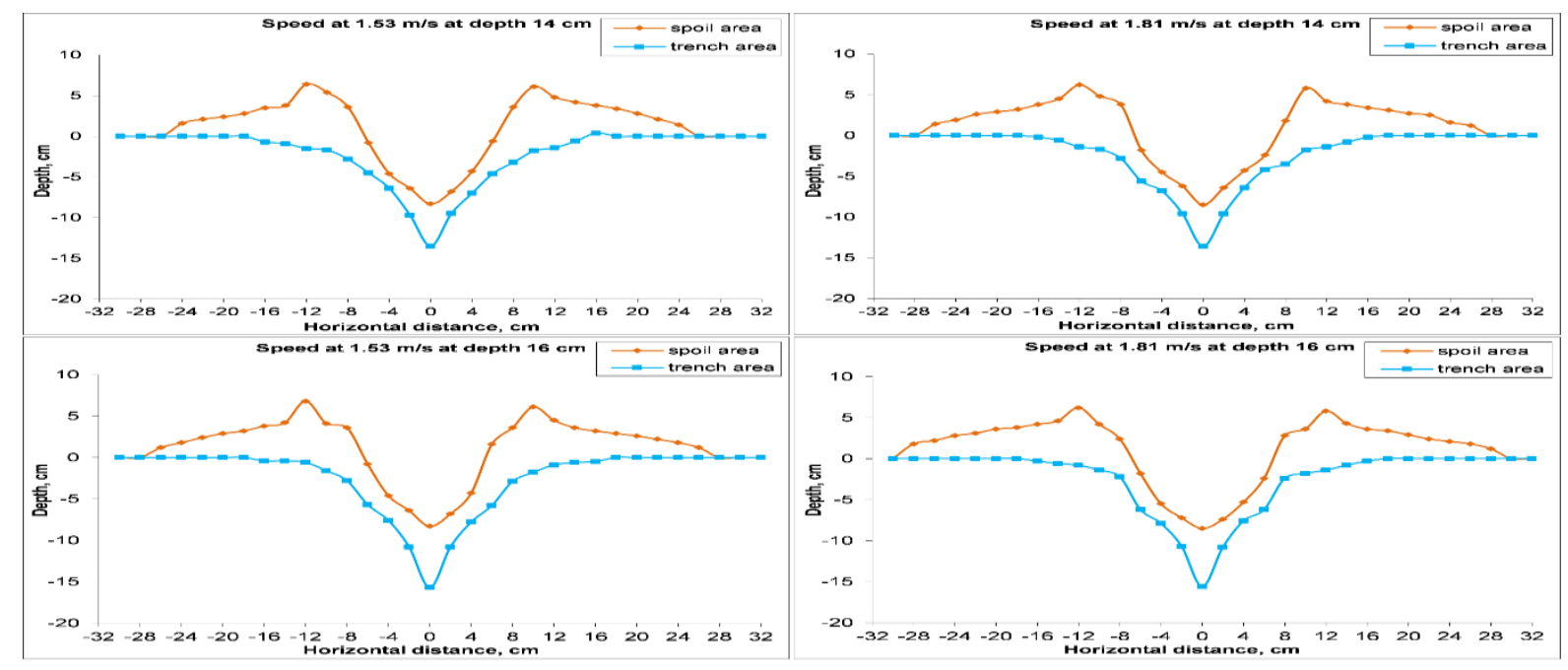
Fig.10 Effect of speed at different depth on spoil area of different shovels

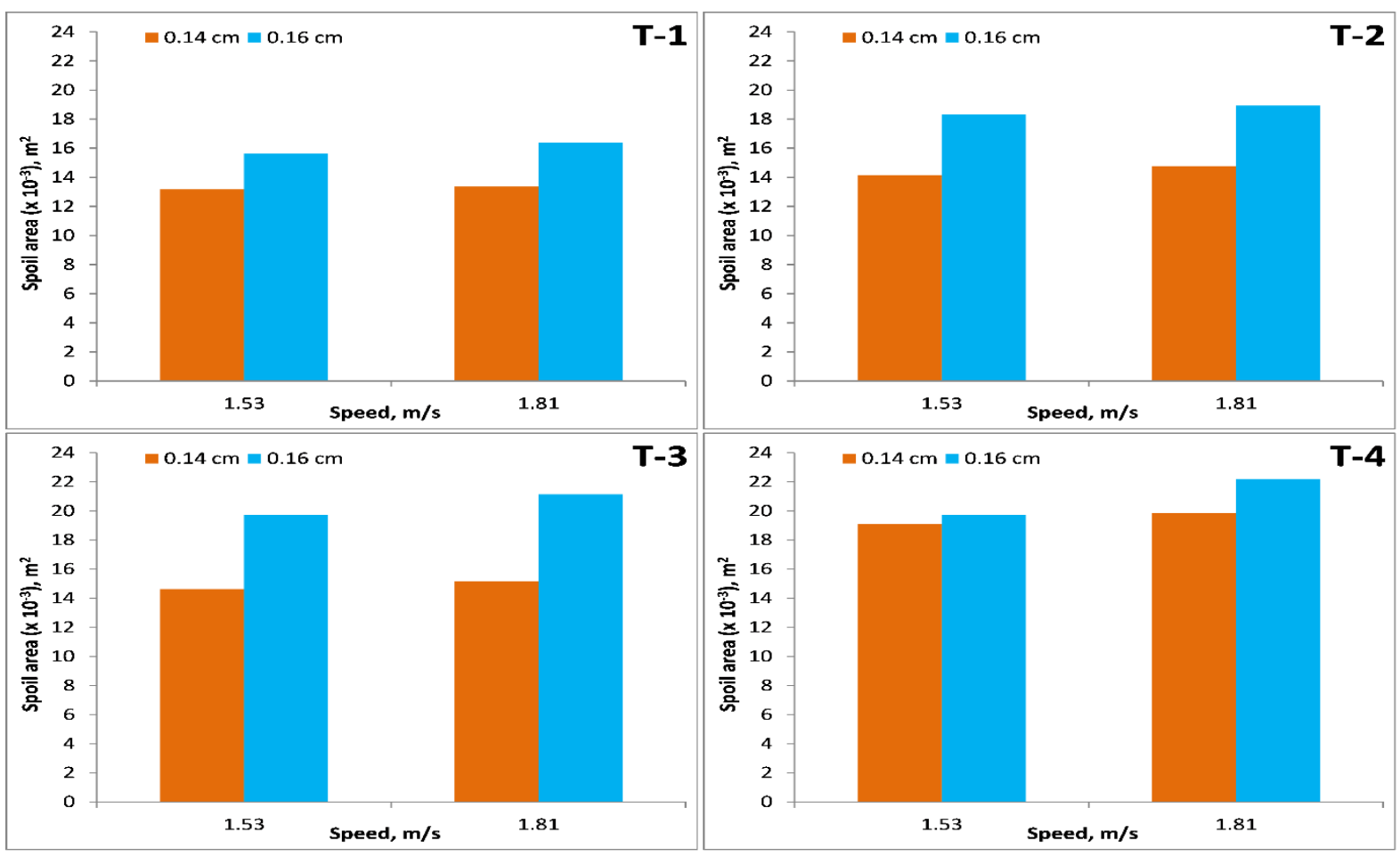

Fig.11 Effect of speed at different depth on trench area of different shovels

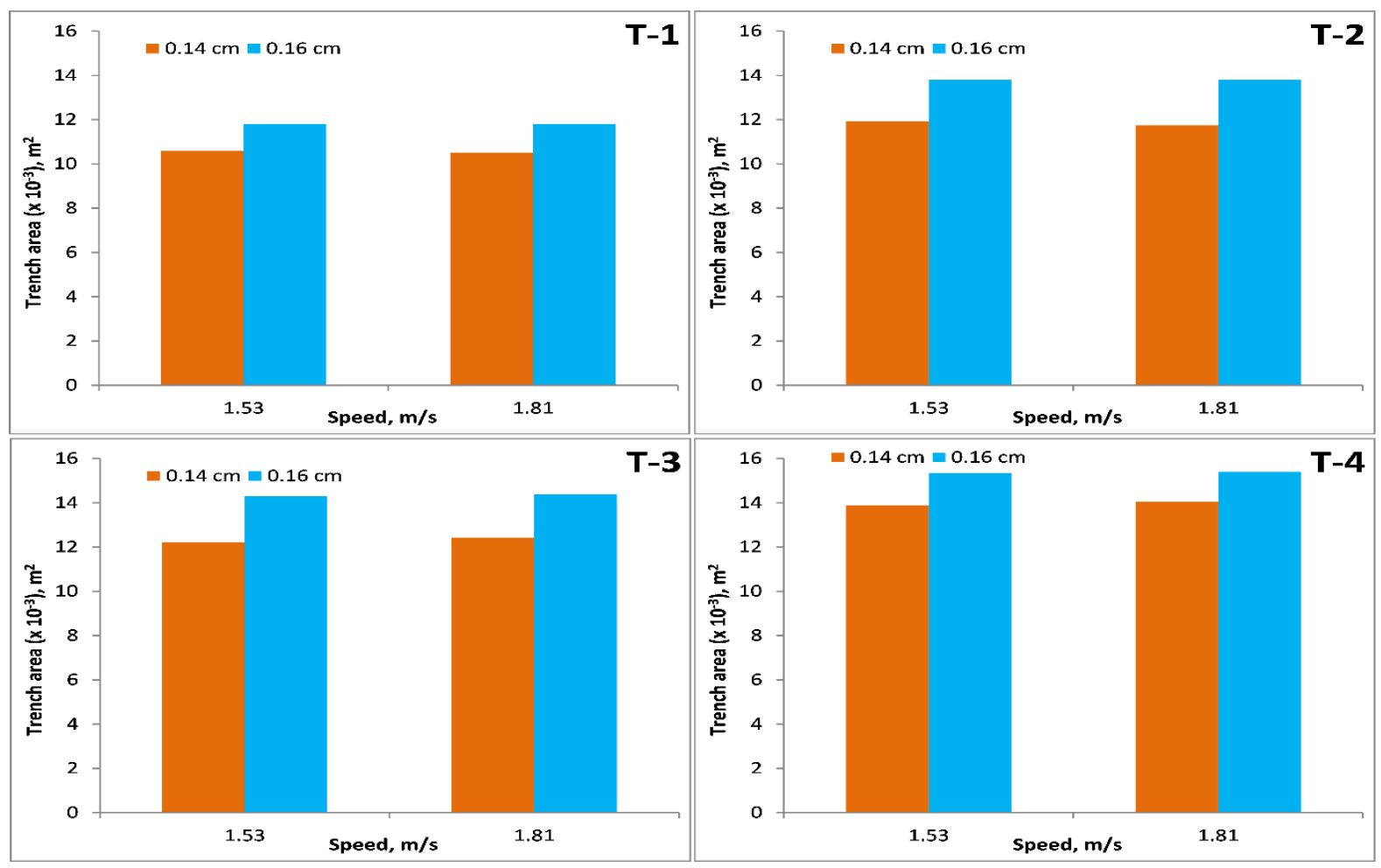




\section{Effect of shovel, speed and depth of operation on trench area}

Figure 11 show that trench area increased with increase in depth and decrease with increase in speed of operation for all shovels. $\mathrm{T}-4$ resulted in more trench area than other all shovels at all depths and speed of operation. This may be due to the wide cross section of the T-4 that disturbed a larger zone of soil than other shovels. In all shovels, the trench area varied all most at steady rate with increase in depth and speed of operation. The effect was more dominant when depth of operation at $16 \mathrm{~cm}$ at all speeds of operation. This may be the effect of the geometrical parameters of the shovel. Similar findings have been reported by Sharifat and Kushwaha (1999) and Mielke et al., (2004).It was found that speed has non-significant effect on trench area at a particular depth of operation for a given shovel. It is also observed that at lower $14 \mathrm{~cm}$ and higher $16 \mathrm{~cm}$ depth of operation, T-2 and T-3 shovels behaved in the similar manner at a given forward speed of operation. This may be attributed to geometrical shape and dimensions of these two shovels.

Conclusions of the study are as follows:

1. Spoil furrow width and depth increased with the increase in depth and speed of operation whereas reverse trend was observed for crescent height which decreased with increase in speed of operation for all shovels.

2. Spoil area was directly proportional to depth and speed of operation whereas, trench area decreased with increase in speed of operation for all shovels. It was depth of operation which affected more the spoil and trench area than speed of operation. T-4 gave highest spoil area $\left(22.190 \times 10^{-3} \mathrm{~m}^{2}\right)$ and trench area $(15.400$ $\mathrm{x} 10^{-3} \mathrm{~m}^{2}$ ) among all the shovels tested.

\section{References}

Chen Y; Monero FV; Lobb D; Tessier SC; Cavers. 2004. Effect of six tillage methods on residue incorporation and crop performance in a heavy clay soil. Transactions of the ASAE. 47 (4): 1003-1010.

Hanna HM; Erbach DC; Marley SJ; Melvin SW. 1993. Comparison of the Goryachkin theory to soil flow on a sweep. Transactions of the ASAE. 36 (2): 293-299.

Himani. 2014. An Analysis of Agriculture Sector in Indian Economy. IOSR Journal of Humanities and Social Science. 19 (1): 47-54.

Jain SC; Grace P. 2003. Farm Machinery an Approach. First Edition. Standard Publishers Distributors, New Delhi.

Klaas; Martens MH. 2005. Part 3 of 3: In row cultivation. The New Farm farmer-tofarmerknow-how from the rotate institute. Available on line http://www.newfarm.org/sendpage/frien d.php.

Liu J; Kushwaha RL. 2006. Modeling of soil profile produced by a single sweep tool. Agricultural Engineering International: the CIGR Ejournal. 8: 1-13.

Mehta CR; Chandel NS; Senthilkumar T; Singh KK.2014. "Trends of Agricultural Mechanization in India."

Mehta CR., Chandel NS., Jena PC., Jha A. 2019. Indian Agriculture Counting on Farm Mechanization. Agricultural Mechanization in Asia, Africa and Latin America. 50: 84-89.

Madhusudhan L. 2015 Agriculture Role on Indian Economy. Bus Eco J6: 176.

Mielke LN., Grisso RD., Bashford LL., Parkhurst AM. 2004. Bi-level subsoiler performance using tandem shanks. Transactions of the ASAE. 30 (2): 345349.

Manchikanti., Sengupta. 2012. Agriculture 
Machinery in India: IPR Perspective. Journal of Intellectual Property Right., 16: 163-169.

Raper, RL. 2005. Force requirements and soil disruption of straight and bentleg subsoilers for conservation tillage systems. Applied Engineering in Agriculture. 21 (5): 787-794.

Raper RL., Sharma AK. 2004. Soil moisture effects on energy requirements and soil disruption of subsoiling a coastal plain soil. Transactions of the ASAE. 47 (6): 1899-1905.

Raper RL., Reeves DW., Burmester CH., Schwab EB. 2000. Tillage depth, tillage timing, and cover crop effects on cotton yield, soil strength, and tillage energy requirements. Applied Engineering in Agriculture. 16 (4): 379-385.

Sapkale PR., Sharma AK., Bastewad TB.,
Mahajan JB. 2011. Influence of Tool Shape and Operating Parameters on Soil disruption of Reversible Shovels for Tractor drawn Cultivator in Sandy loam Soil. Agriculture Engineering 36 (1):108-112.

Sapkale PR., Sharma AK., Bastewad TB., Mahajan JB. 2010. Effect of tool shape and operating parameters on soil disruption of cultivator sweeps in sandy loam soil. International Journal of Agricultural Engineering, 3(2): 192198.

Sharifat K., Kushwaha RL.1999. Lateral soil movement by tillage tools. ASAE paper No. 991003. St. Joseph, Mich.: ASAE.

Yadav BK., Mani, I. and Panwar SJ. 2006. Relationship between disc geometry and draft requirement. Journal of Agricultural Engineering. 43 (1): 49-52.

\section{How to cite this article:}

Abhinav Yadav, Ajay Kumar Sharma, Vipin Laddha, Manpreet Singh, Brajesh Kumar and Anurag Yadav. 2020. Influence of Tool Geometry of Reversible Shovel on Soil Disruption. Int.J.Curr.Microbiol.App.Sci. 9(12): 1730-1740. doi: https://doi.org/10.20546/ijcmas.2020.912.205 